Chirurgia (2018) 113: 551-557

No. 4, July - August

Copyright@ Celsius

http://dx.doi.org/10.21614/chirurgia.113.4.551

\title{
Laparoscopic Management in Morgagni Hernia - Short Series and Review of Literature
}

\author{
Eugen Târcoveanu, Ștefan Georgescu, Alin Vasilescu, Dan Andronic, Nicolae Dănilă, Cristian Lupașcu, Costel Bradea
}

First Surgical Clinic, Department of Surgery, "Grigore T. Popa” University of Medicine and Pharmacy lași University Hospital "St. Spiridon" Iași, Romania

Corresponding author:

Dr. Alin Vasilescu, MD, PhD

First Surgical Clinic

Department of Surgery

"Grigore T. Popa" University of Medicine and Pharmacy lași, Romania

University Hospital "St. Spiridon" lași

Independentei Street, no. 1, 700111, RO

E-mail: vasilescu.alin@gmail.com

\section{Rezumat}

Tratamentul laparoscopic în hernia Morgagni - serie de cazuri și analiza literaturii

Hernia Morgagni (HM) se dezvoltã în urma unui defect diafragmatic retrosternal congenital, fiind o formã rarã de hernie diafragmaticã (1-3\% din cazuri). În general aceastã patologie este diagnosticatã la copii, iar la adulti poate fi descoperitã în urgentã. Material şi metodă: Am evaluat prospectiv o serie de 8 pacienți internați în Clinica I Chirurgie, Sp. Sf. Spiridon, Iaşi în perioada 2011-2017.

Rezultate: Din 8 pacienți, 6 au fost operați, unul refuzând intervenția chirurgicală, dar care este urmărit periodic, iar altul de 91 ani avea contraindicații majore pentru tratamentul chirurgical. Simptomatologia a fost nespecifică: în 5 cazuri, HM au fost descoperite cu ocazia explorărilor pentru o patologie asociatã; alți bolnavi aveau simptomatologie cardiopulmonară cu dispnee sau palpitații. În 2 cazuri tabloul clinic a sugerat un sindrom ocluziv (organul herniat fiind de obicei colonul transvers). Abordul laparoscopic a fost utilizat în toate cazurile, înregistrându-se 2 conversii, datorită aderențelor strânse intrasaculare a viscerelor herniate (antru gastric, colon, epiplon). În 4 cazuri s-a practicat cura chirurgicală a herniei procedeul anatomic, iar în 2 cazuri cu plasă: duală într-un caz şi polipropilena în alt caz. $\mathrm{Nu}$ am înregistrat complicații, spitalizarea postoperatorie fiind de 4 zile (2-6 zile).

Concluzii: Hernia Morgagni este o patologie rară. Cel mai frecvent este asimptomatică, dar în cazurile complicate poate fi o cauză de abdomen acut chirurgical. Tratamentul chirurgical este indicat chiar şi pentru cazurile asimptomatice datorită complicațiilor
Received: 26.07.2017 Accepted: 22.09.2017 
grave spre care poate evolua. Abordul laparoscopic este ideal, reducerea viscerelor în abdomen fiind facilă, iar defectul diafragmatic poate fi reparat, în funcție de dimensiuni, prin sutură sau utilizarea unei proteze.

Cuvinte cheie: hernie Morgagni, hernie diafragmatică, abord laparoscopic

\section{Abstract}

Morgagni hernia occurs after a congenital retrosternal diaphragmatic defect; it is a rare form of diaphragmatic hernia (1-3\% of cases). In general, this pathology is diagnosed in children; in adults it is frequently discovered in emergency or incidentally.

Methods: We prospectively evaluated a series of 8 patients admitted to First Surgical Clinic, St. Spiridon Hospital, Iasi during the period 2011-2017.

Results: Out of 8 patients, 6 were operated on, one patient refusing surgery (followed periodically); the patient who was 91 years old had serious associated diseases that made surgery contraindicated. Symptomatology was nonspecific: in 5 cases Morgagni hernia was discovered during the exploration of an associated pathology, either with cardiopulmonary symptoms of dyspnea or palpitations. In 2 cases, the clinical aspect suggested an occlusive syndrome (the herniated organ is usually the transverse colon). The laparoscopic approach was used in all cases: two conversions were recorded due to the tight adherences of the herniated viscera (gastric, colon, epiplon). In 4 cases, the surgical cure of hernia was performed by suture and in 2 cases with prosthesis: dual mesh in one case and polypropylene mesh in another case. We did not register morbidity and the mean postoperative stay was 4 days (range $2-6$ days).

Conclusions: Hernia Morgagni betrays a rare pathology. The most common is asymptomatic but in complicated cases it is a cause of acute surgical abdomen. Surgical treatment is indicated even for asymptomatic cases due to serious complications Morgagni hernia may develop. The laparoscopic approach is ideal, as reduction of viscera in the abdomen is easy and the defect will be repaired by suturing or using a prosthesis, depending on its size.

Key words: Morgagni hernia, diaphragmatic hernia, laparoscopic approach

\section{Introduction}

Morgagni hernia (MH) is a rare form of diaphragmatic hernia (1-3\% of cases), usually diagnosed in children; in adults, it is frequently discovered in emergency or incidentally, imagistically or intraoperatively $(1,2)$. Symptomatology is nonspecific so diagnosis is suggested by imaging exploration (gold standard computer tomography - CT). The treatment consists in closing the defect with or without the use of prosthesis by abdominal or thoracic way, an open or minimal invasive approach (3).

\section{Materials and Methods}

We prospectively studied the patients diagnosed with Morgagni hernia, admitted to the First Clinic of Surgery, between 2010 - 2017. The patients who accepted the surgical intervention and signed informed consent and had no major contraindications of surgical treatment were treated as a first intention by laparoscopic approach. Immediate and late results were analyzed to verify the safety of the laparoscopic aproach. All further patients admitted in our department with confirmed Morgagni hernia were included in the study. 


\section{Results}

Between 2010 and 2017, 8 patients were admitted to our clinic, mainly women ( 7 women and one male), aged 50 and 91 years old, with an average age of 65.87 years (Table 1). One patient refused surgery; the patient who was 91 years old had serious associated diseases that contraindicated surgery. The remaining 6 patients were operated on laparoscopically. In 2 cases the colon in the hernia sac was fixed by adherence, requiring conversion.

Obesity (present in 6 patients) was a contributing factor to the pre-existing parietal defect. Clinical signs were predominantly abdominal (pains, nausea, vomiting, transit disorders) present in 7 patients, plus chest signs (dyspneea, cough) in the case of 3 patients. Significant changes occurred on chest X-ray (Fig. 1), front and profile (4 out of 8 cases), abdominal ultrasound (5 out of 8 cases), and all $\mathrm{CT}$ cases (Fig. 2). Table 1 presents demographic data and clinical features of the patients.

The hernia was located in 7 of 8 cases at the right of the xifoid appendix (Fig. 3). The size of

Table 1. Demographic data and preoperative diagnosis

\begin{tabular}{|c|c|c|c|c|c|c|c|c|c|c|}
\hline \multirow[t]{3}{*}{ Sex } & \multirow[t]{3}{*}{ Age } & \multirow[t]{3}{*}{$\begin{array}{l}\text { Morgagni } \\
\text { hernia site }\end{array}$} & \multirow[t]{3}{*}{ Complications } & \multicolumn{4}{|c|}{ Main symptoms/signs } & \multicolumn{3}{|c|}{$\begin{array}{c}\text { Imaging suggestive for Morgagni } \\
\text { hernias }\end{array}$} \\
\hline & & & & & & & & $\begin{array}{l}\text { Ultrasound } \\
\text { scan }\end{array}$ & $\begin{array}{cc}\text { CT } \\
\text { scan }\end{array}$ & $\begin{array}{l}\text { Radiologic features } \\
\text { suggestive for MH }\end{array}$ \\
\hline & & & & Asymptomatic & $\begin{array}{l}\text { Thoracic } \\
\text { symptoms }\end{array}$ & $\begin{array}{l}\text { Abdominal } \\
\text { symptoms }\end{array}$ & $\begin{array}{l}\text { Associate } \\
\text { diseases }\end{array}$ & & Size cm & Size cm \\
\hline $1 \mathrm{~F}$ & 50 & Right & - & & & Pain, nausea & Obesity & $\mathrm{Y} /+\mathrm{I}$ & $Y+/ 13 / 9$ & $\mathrm{Y} /+/ 11 / 8$ \\
\hline $2 \mathrm{M}$ & 59 & Right & irreducible & & & Pain, nausea & Obesity, HTA & $\mathrm{Y} /+$ & N/- & $Y /+/ 8 / 4$ \\
\hline $3 \mathrm{~F}$ & 69 & Right & irreducible & $\begin{array}{l}\text { Incidental finding } \\
\text { (cholecystectomy) }\end{array}$ & + & Pain, nausea & $\begin{array}{l}\text { Obesity, FA,CC, } \\
\text { Inguinal hernia }\end{array}$ & $\mathrm{Y} /-$ & N/- & Y/-- \\
\hline $4 \mathrm{~F}$ & 59 & Left & - & & & Pain, Dyspepsia & Obesity, CC & $Y /+$ & $\mathrm{Y} /+$ & $Y /-+$ \\
\hline $5 F$ & 71 & Right & - & & + & Pain, nausea & & $\mathrm{Y} /+$ & $Y /+/ 10 / 9$ & $Y /+13 / 7$ \\
\hline $6 \mathrm{~F}$ & 91 & Right & - & & & Pain, Vomiting & & $\mathrm{Y} /-$ & N/- & $Y /-$ \\
\hline $7 \mathrm{~F}$ & 72 & Right & - & & & Pain, nausea & Obesity & $\mathrm{Y} /+$ & $\mathrm{N} /-$ & Y/-- \\
\hline $8 \mathrm{~F}$ & 56 & Right & - & & + & Pain, nausea & Obesity & $\mathrm{Y} /+$ & $Y /+11 / 8$ & $Y /+/ 10 / 8$ \\
\hline
\end{tabular}

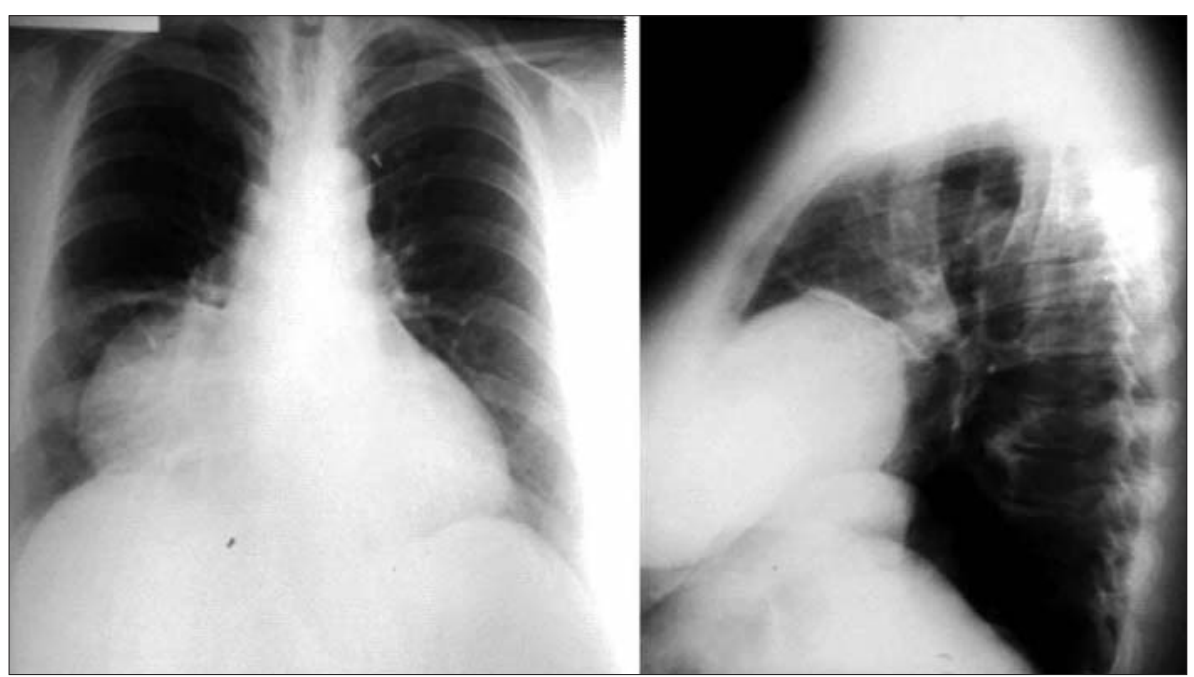

Figure 1. Morgagni hernia - chest radiography: paracardiac right, opacity of medium intensity projected anterior in the costo - diaphragmatic sinus, large, homogeneous, 90/80 mm 

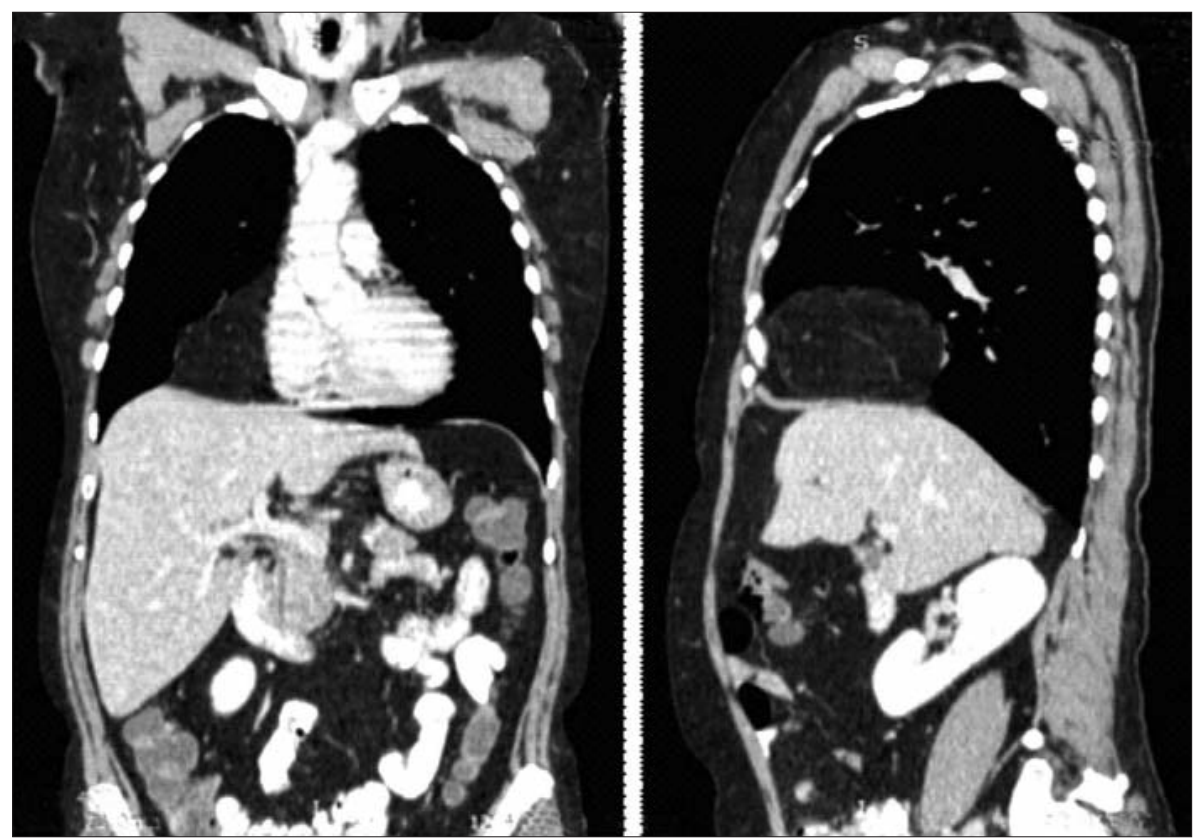

Figure 2. Morgagni hernia - CT: mass $110 \times 80 \mathrm{~mm}$, precisely defined, homogeneous, containing the falciform ligament and gastro-colonic epiploon, anterior located in the lower and middle mediastinum, compressing the adjacent pulmonary parenchyma
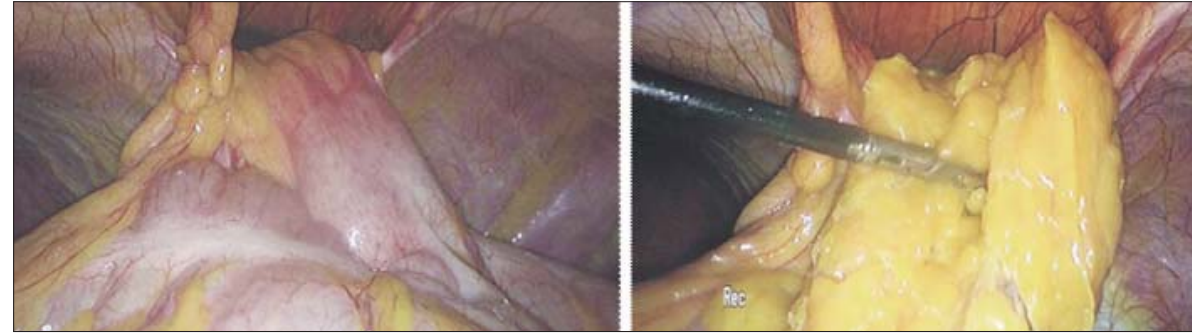

Figure 3. Morgagni hernia - intraoperative view: laparoscopic approach, exploration and content of the sac reduction

the herniar defect was between 5 and $10 \mathrm{~cm}$, averaging $7 \mathrm{~cm}$. The most common herniated organ was the large epiploon (5 cases) associated or not with the transverse colon (4 cases), or the stomach (2 cases). The defect was sutured with separate non-resorbable threads in 3 cases with a defect below $8 \mathrm{~cm}$ and prosthesis with dual prosthesis in 2 cases where the diameter of the diaphragmatic defect was over $8 \mathrm{~cm}$ (Fig. 4 and 5). The sac was resected in 4 of the 6 cases that were operated on. The duration of the intervention was on average 65 minutes: In 2 cases it was associated with 2 cholecystectomies and operculectomy for hepatic hydatic cyst. The postoperative evolution was good in all cases. Postoperative stay was on average 3,5 days for laparoscopically completed cases and 7 days for those who were converted to open surgery. Folow-up, on average after 4.5 years by imagistic methods, did not show relapse (Table 2).

\section{Discussion}

The first necroptic description was made by Giovanni Battista Morgagni in 1769 (4). Disease usually occurs in children, where statistics exceed 20 observations and chromosome abnormalities (15\%). In $75 \%$ of cases, a congenital abnormality such as Down 

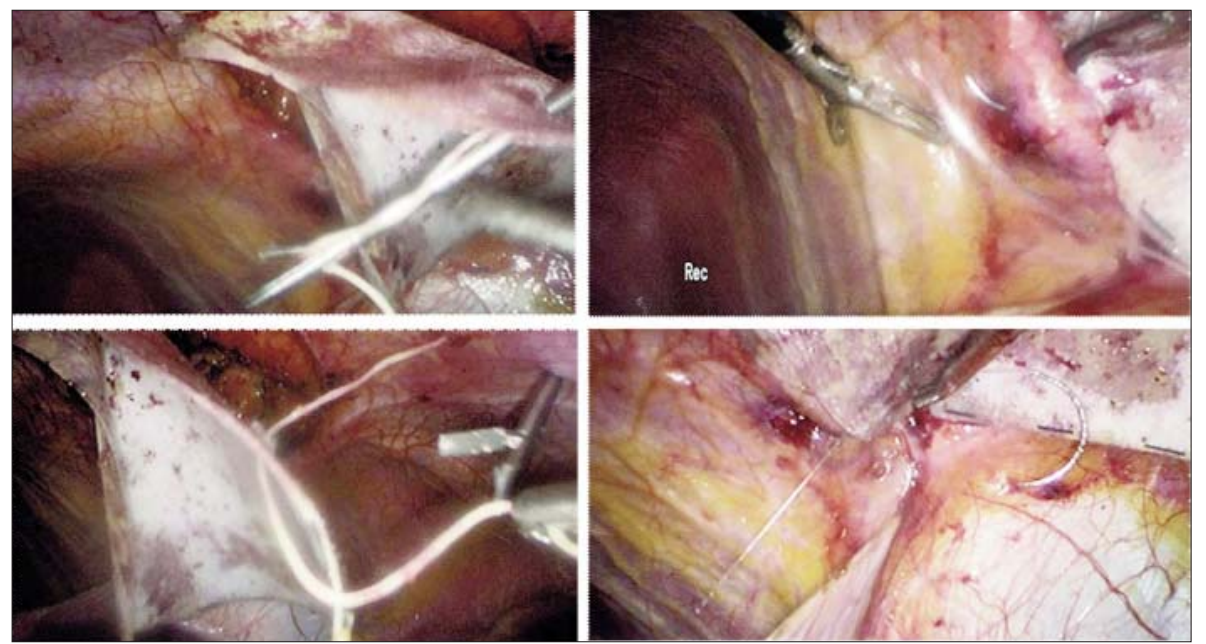

Figure 4. Morgagni hernia - intraoperative view: mesh fixation with Reverdin needle and suture

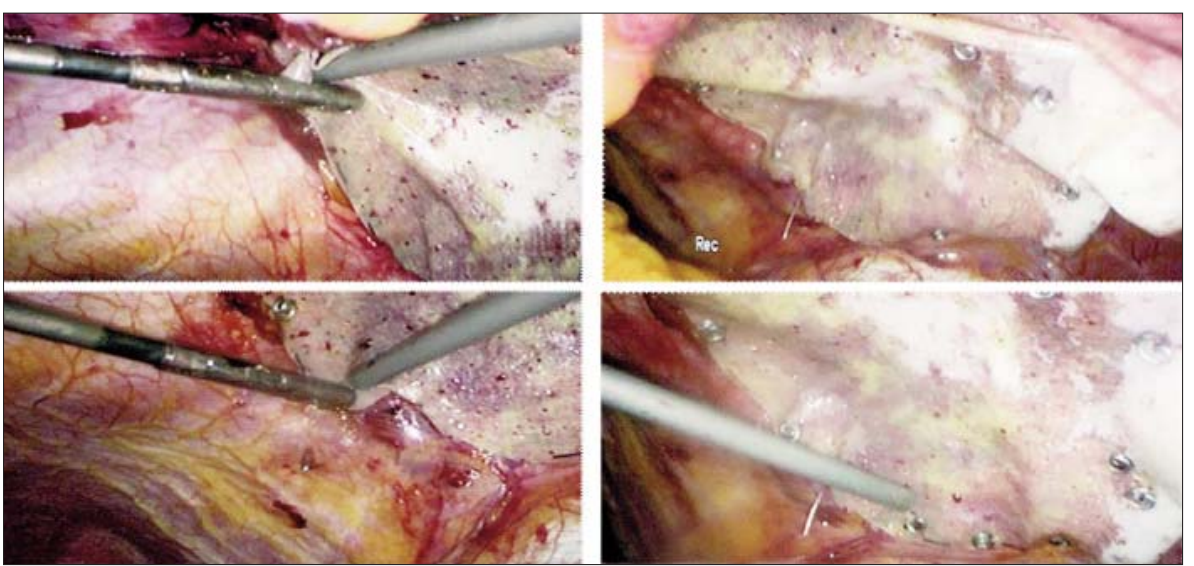

Figure 5. Morgagni hernia - intraoperative view: mesh fixation with $5 \mathrm{~mm}$ protack with permanent taks

Table 2. Surgical approach, immediate results and follow-up

\begin{tabular}{|c|c|c|c|c|c|c|c|c|c|}
\hline & Sex & Age & $\begin{array}{c}\text { Defect size } \\
\text { Cm }\end{array}$ & Surgical treatment & $\begin{array}{c}\text { Contents of hernia } \\
\text { sac }\end{array}$ & $\begin{array}{l}\text { Associated } \\
\text { procedures }\end{array}$ & $\begin{array}{l}\text { Hospital stay } \\
\text { (days) }\end{array}$ & $\begin{array}{c}\text { Follow-up } \\
\text { (years) }\end{array}$ & Recurrence \\
\hline 1 & $\mathrm{~F}$ & 50 & 5 & Laparoscopic suture & epiploon & & 3 & 3 & no \\
\hline 2 & $\mathrm{M}$ & 59 & 6 & $\begin{array}{c}\text { laparoscopic approach } \\
\text { conversion } \\
\text { (adhesions) suture }\end{array}$ & $\begin{array}{l}\text { epiploon, } \\
\text { transverse colon }\end{array}$ & & 7 & 7 & no \\
\hline 3 & $\mathrm{~F}$ & 69 & 8 & $\begin{array}{c}\text { laparoscopic } \\
\text { cholecystectomy - } \\
\text { conversion (adhesions) } \\
\text { suture }\end{array}$ & & $\begin{array}{c}\text { laparoscopic } \\
\text { cholecystectomy }\end{array}$ & 8 & 5 & no \\
\hline 4 & $\mathrm{~F}$ & 59 & 6 & refuse & epiploon & & 4 & 2 & no \\
\hline 5 & $\mathrm{~F}$ & 71 & 10 & laparoscopic mesh & $\begin{array}{l}\text { epiploon, transverse } \\
\text { colon }\end{array}$ & & 4 & 2 & no \\
\hline 6 & $\mathrm{~F}$ & 91 & 6 & contraindications & $\begin{array}{l}\text { stomach, epiploon, } \\
\text { transverse colon }\end{array}$ & & 4 & 4 & no \\
\hline 7 & $\mathrm{~F}$ & 72 & 5 & laparoscopic suture & - & $\begin{array}{c}\text { laparoscopic } \\
\text { cholecystectomy, lap } \\
\text { treatment of HHC }\end{array}$ & 6 & 2 & no \\
\hline 8 & E & 56 & 9 & laparoscopic mesh & - & & 3 & 4 & no \\
\hline
\end{tabular}


syndrome, ventricular septal defect, pectus carinatum, omphalocele, intestinal malrotation, cryptorchidia are associated. Incidence is 1 to 2,000 births $(5,6)$. Malformations are rarely found in adults (7).

HM is produced by a defect resulting in the anterior diaphragm, between the transverse septum and its costal insertion. The diaphragmatic defect is more often on the right between the xifoid and the $7^{\text {th }}$ rib, where the upper epigastric vessels pass (90\%); but it may also be on the left. This happens rarely $(2 \%)$ because the pericardial sac covers the defect (Larey hernia), or bilaterally (8\%) (8).

In the case of children, Morgagni hernia is more common in boys. In the case of adults, women are more predisposed, as in our group. In adults, even the elderly, HM is incidentally discovered (81 asymptomatic cases published), imagistically or intraoperatively; or in the case of complications (2\%) (intestinal or colon intestinal occlusion, gastric volvulus, large epiploon incarceration) $(9,10)$. In $50 \%$ of cases, predisposing factors are encountered: obesity, multiparity, chronic obstructive pulmonary disease, constipation (11). Symptomatic cases were found in patients with non-specific gastro-intestinal and respiratory signs after CT (gold standard) investigation. Adult clinical signs are more common (dyspepsia) (12) than in our cases.

The signs, also in the case of children, are respiratory $(56.5 \%)$, gastrointestinal $(19 \%)$, or combined (6.8\%); The diagnosis is determined by chest x-ray, ultrasound, CT (6). Diagnosis can also be performed prenatally. In adults, the diagnosis is late because most of the symptoms are gastrointestinal (gastric pain, nausea, vomiting) and cardiopulmonary (palpitations, cough, dyspnoea). In an emergency, the clinical picture suggests an occlusive syndrome (the herniated organ is usually the transverse colon) or very rarely peritoneal (through the bowel perforation following necrosis) or the incarceration of the large epiploon. Rarely the clinical picture suggests pyloric stenosis (13).

Differential diagnosis includes pneumonia, pulmonary atelectasis, diaphragmatic eventration, mediastinal lipoma, liposarcoma, abscess, pleuropericardial cyst, thymoma, pleural mesothelioma, diaphragmatic tumors or cysts, anterior thoracic wall tumors (14).

In $50 \%$ of adult cases a number of predisposing factors were identified: obesity, multiparity, chronic obstructive pulmonary disease, constipation. In our series, obesity was encountered in six out of eight patients. Morgagni hernia usually has a sac. The preexistence of a congenital diaphragmatic defect, in the conditions of abdominal hyperpression, forces the viscera to penetrate into the sac: large epiploon, colon, stomach, liver (in child), or other viscera.

Treatment of Morgagni hernia, once diagnosed, is surgical to prevent complications $(15,16)$. Until 1980 only the symptomatic forms were operated on. Anesthetic problems occur in the case of children and the elderly $(17,18)$.

The approach can be abdominal (classic or laparoscopic) or thoracic (classic or thoracoscopy). The abdominal aproach is preferred because: easy reduction of herniated viscera allows diagnosis of bilateral forms and treatment of associated diseases. It is indicated in complicated forms. The thoracic approach, can not evaluate bilateral forms and requires pleural drainage. Laparoscopy is today preferred $(19,20)$. The first laparoscopic intervention was reported in 1992 by Kuster G.G.R. (21), while the first laparoscopic repair was performed by St. Georgescu in Iasi (16). Laparoscopy allows a very clear assessment of the defect, allowing the wall to be restored by suture (in the case of a defect that is less than $6 \mathrm{~cm}$ ) or the use of a prosthesis (defect over $7 \mathrm{~cm})(21,22)$. Dual meshs are recommended. The sac may be excised or may be left in place (23). Excision of the sac can cause pneumo-thorax and circulatory and respiratory complications and can damage the pericardial or other mediastinal structures.

The laparoscopic approach becomes a gold standard, even in the case of children. An alternative solution to standard laparoscopic treatment is percutaneous suture of the diaphragmatic defect using a single umbilical trocar $(24,25)$. The first case operated with the Da Vinci robot was reported (26). Advantages 
of laparoscopy are well-known: short operative time, fewer postoperative analgesics, rapid recovery, short hospitalization and positive cosmetic aspect. The relapse rate is below $2 \%$, especially in the case of large defects, when is not tension free $(27,28)$.

\section{Conclusions}

Morgagni hernia is a rare adult pathology. The most common form is asymptomatic, but in complicated cases it can even be the cause of acute surgical abdomen. Diagnosis is based on imaging methods (chest X-ray, CT, MRI). Surgical treatment is indicated even for asymptomatic cases due to serious complications to which it may evolve otherwise. The laparoscopic approach is ideal due to its benefits as it is a minimally invasive approach. Reducing the viscera in the abdomen is easy; the herniar sac is generally excised if there are no risks, and the defect will be repaired, depending on size, by suture or using dual prosthesis.

\section{Conflicts of Interest}

No conflict of interest.

\section{Authors' Contributions}

All have equal contributions

\section{References}

1. Oguma J, Ozawa S, Kazuno A, Nitta M, Ninomiya Y. Laparoscopic mesh repair of adult diaphragmatic hernia: A report of two cases. Asian J Endosc Surg. 2017;10(2):179-82.

2. Yoldas T, Ustun M, Karaca C, Firat O, Caliskan C, Akgun E, Korkut M. Morgagni hernia: is it just a congenital hernia or a cause of emergency surgery? Am Surg. 2016;82(11):317-19.

3. Napolitano L, Waku M, Di Fulvio A, Maggi G, Ciarelli F. Diaphragmatic hernia report of two cases, classification, and review of literature. Ann Ital Chir. 2016;87:422-25.

4. Morgagni GB. The seats and causes of diseases investigated by anatomy; in five books, containing a great variety of dissections, with remarks. London: A. Millar; T. Cadell; 1769.

5. Patial T, Negi S, Thakur V. Hernia of Morgagni in the elderly: a case report. Cureus. 2017;9(8):e1549.

6. Golden J, Barry WE, Jang G, Nguyen N, Bliss D. Pediatric Morgagni diaphragmatic hernia: a descriptive study. Pediatr Surg Int. 2017;33(7):771-75.

7. Radionov M, Ziya DD, Nedevska M. Giant Morgagni hernia in a female with malrotation syndrome and thoracic transposition of small bowel, cecum, ascending and transverse colon. Khirurgiia
(Sofiia). 2015;81(3):142-8.

8. Alonso Arroyo V, Morcillo Azcárate J, Pérez Bertólez S, Soares Medina A, Vivas Colmenares G, Requena Díaz M et al. MorgagniLarrey anterior diaphragmatic hernias. Review of 13 cases. Cir Pediatr. 2017;30(4):175-79.

9. Modi M, Dey AK, Mate A, Rege S. Strangulated Morgagni's hernia: a rare diagnosis and management. Case Rep Surg. 2016; 2016: 2621383.

10. Razi K, Light D, Horgan L. Emergency repair of Morgagni hernia with partial gastric volvulus: our approach. J Surg Case Rep. 2016;8:1-3

11. Pattnaik MK, Sahoo SP, Panigrahy SK, Nayak KB. Morgagni hernia: A rare case report and review of literature Lung India. 2016;33(4):427-29.

12. Kim DK, Moon HS, Jung HY, Sung JK, Gang SH, Kim MH. An incidental discovery of Morgagni hernia in an elderly patient presented with chronic dyspepsia. Korean J Gastroenterol. 2017; 69(1):68-73.

13. Kumar A, Bhandari RS. Morgagni hernia presenting as gastric outlet obstruction in an elderly male. J Surg Case Rep. 2016;7:1-4.

14. Pillai $S A$, Chinnappan S. Congenital right Morgagni hernia presenting in an adult-a case report. Indian J Surg. 2016;78(3):238-40.

15. Arora S, Haji A, Ng P. Adult Morgagni hernia: the need for clinical awareness, early diagnosis and prompt surgical intervention. Ann R Coll Surg Engl. 2008;90(8):694-5.

16. Georgescu SO, Crumpei F, Cijevschi Prelipcean C. Morgagni hernia - laparoscopic approach. Jurnalul de chirurgie (lasi). 2013; 9(3): 269-74.

17. Nama RK, Butala BP, Shah VR, Patel HR. Anesthetic management of Morgagni hernia repair in an elderly woman. Anesth Essays Res. 2015;9(3):413-16.

18. Kozanhan B, Basaran B, Aygın F, Akkoyun I, Özmen S. Anaesthetic management of laparoscopic Morgagni hernia repair in a patient with coexisting Down syndrome, patent foramen ovale and pectus carinatum. Turk J Anaesthesiol Reanim. 2016;44(1):44-6.

19. Godazandeh G, Mokhtari-Esbuie F. Laparoscopic repair of Morgagni hernia: three-case presentation and the literature. Case Rep Surg. 2016;2016:4268539.

20. Esposito C, Escolino M, Varlet F, Saxena A, Irtan S, Philippe P, et al. Technical standardization of laparoscopic repair of Morgagni diaphragmatic hernia in children: results of a multicentric survey on 43 patients. Surg Endosc. 2017;31(8):3320-25.

21. Kuster G.G.R., Kline LE, Garzo G. Diaphragmatic hernia through the foramen of Morgagni: laparoscopic repair case report. Journal of Laparoendoscopic Surgery. 1992;2(2):93-100.

22. Loong TP1, Kocher HM. Clinical presentation and operative repair of hernia of Morgagni. Postgrad Med J. 2005;81(951):41-4.

23. Lamas-Pinheiro R, Pereira J, Carvalho F, Horta P, Ochoa A, Knoblich M, et al. Minimally invasive repair of Morgagni hernia - A multicenter case series. Rev Port Pneumol (2006). 2016; 22(5): 273-8.

24. Yilmaz E, Afsarlar CE, Erdogan D, Ozguner IF. Outpatient single-port laparoscopic percutaneous Morgagni hernia repair assisted by an optical forceps. Minim Invasive Ther Allied Technol. 2017; 26(3):182-7.

25. Zouari $M$, Jallouli $M$, Bendhaou M, Zitouni $H$, Mhiri R. Percutaneous suturing technique and single-site umbilical laparoscopic repair of a Morgagni hernia: Review of three cases. Arch Pediatr. 2015:22(12):1272-5.

26. Arevalo G, Harris K, Sadiq A, Calin ML, Nasri B, Singh K. Repair of Morgagni hernia in adults with primary closure and mesh placement: first robotic experience. J Laparoendosc Adv Surg Tech A. 2017;27(5):529-32.

27. Jaiswal SS, Pujahari AK, Mehra R, Singh G.Congenital Morgagni hernia. Med J Armed Forces India. 2015;71(4):396-9.

28. Slepov 0, Kurinnyi S, Ponomarenko 0, Migur M. Congenital retrosternal hernias of Morgagni: Manifestation and treatment in children. Afr J Paediatr Surg. 2016;13(2):57-62. 